\title{
Molecular and biochemical characterization of the effects of insecticidal toxin from meloidae beetles on Helicoverpa armigera (Hub.) (Lepidoptera: Noctuidae)
}

\author{
R.A. Khan', M. Rashid ${ }^{1}$, D. Wang ${ }^{2}$ and Y.L. Zhang ${ }^{1}$ \\ ${ }^{1}$ Key Laboratory of Plant Protection Resources and Pest Management, \\ Ministry of Education, College of Plant Protection, \\ Northwest A\&F University, Yangling, Shaanxi, China \\ ${ }^{2}$ Institute of Entomology, Northwest A\&F University, Yangling, Shaanxi, China \\ Corresponding authors: Y. L. Zhang / D. Wang \\ E-mail: yalinzh@yahoo.com.cn / wanghande@yahoo.com
}

Genet. Mol. Res. 12 (4): 4393-4404 (2013)

Received October 17, 2012

Accepted April 27, 2013

Published October 10, 2013

DOI http://dx.doi.org/10.4238/2013.October.10.5

\begin{abstract}
The molecular and biochemical effects of an insecticidal toxin extracted from Meloidae beetles were investigated on Helicoverpa armigera. The toxin was identified as cantharidin, a well-known natural compound produced by beetles of family Meloidae and Oedemeridae. Furthermore, the effect of the toxin on the metabolic enzymes alkaline phosphatase (ALP) and glutathione $S$-transferase (GST), responsible for the metabolism of insecticides, was also investigated. Results of a diet incorporation bioassay performed under laboratory conditions showed that the $\mathrm{LC}_{50}$ value of cantharidin was $0.068 \mathrm{mg} / \mathrm{g}$. The body weight of the insect was also significantly reduced by cantharidin treatment. The $\mathrm{LC}_{10}$ concentration of cantharidin, $0.01 \mathrm{mg} / \mathrm{g}$, was also tested to determine its effect on ALP and GST. Our results showed that cantharidin significantly inhibited ALP activity after $48 \mathrm{~h}$, whereas GST activity was significantly inhibited after $24 \mathrm{~h}$. The decline of ALP
\end{abstract}


and GST transcript levels was also validated by semiquantitative RTPCR analysis. It may be concluded from the results that ALPs and GSTs may be targets of the cantharidin intoxication mechanism. Moreover, the inability of ALP and GST to metabolize cantharidin shows that the mechanism of detoxification for cantharidin is different from that for conventional insecticides. On the basis of our investigations, the chemical structure of insecticides may be modified using a model structure of cantharidin, to avoid metabolism by metabolic enzymes.

Key words: Cantharidin; Helicoverpa armigera; Alkaline phosphatase; Glutathione $S$-transferase

\section{INTRODUCTION}

Helicoverpa armigera Hub. (Lepidoptera; Noctuidae), commonly known as the cotton bollworm or American bollworm, is distributed worldwide and considered a serious pest of many economic crops. Its presence has been reported in Asia, Europe, Australia, and Africa (EPPO, 1996). This pest is responsible for loses of US \$2 billion to crops annually (ICRISAT, 2003). Amongst cotton pests, $H$. armigera is regarded as a major pest infesting cotton. Other than cotton, this pest is also responsible for losses to legumes and many other crops (Bhatnagar et al., 1982).

$H$. armigera attained the status of primary pest of cotton owing to the indiscriminate and injudicious use of insecticides, especially in the 1980s and 1990s. The management of this pest has never been easy because of the development of resistance to several classes of insecticides. The field population of $H$. armigera has shown moderate to high levels of insecticide resistance to organophosphate and pyrethroid insecticides (Ahmed et al., 1995). One of the reasons for the rapid resistance development has been due to the excessive use of a particular class of compounds (Ramasubramanian and Regupathy, 2004).

Several mechanisms of insecticide resistance have been attributed to resistance in $H$. armigera. These mechanisms include increased rate of insect metabolism (Ahmed and McCaffery, 1991), decreased nerve sensitivity (West and McCaffery, 1992), and a mechanism that reduces the penetration of insecticides (Gunning et al., 1991; Armes et al., 1992; Kennaugh et al., 1993).

Metabolic resistance includes the action of insect metabolic enzymes such as alkaline phosphatase (ALP), glutathione $S$-transferase (GST), carboxylesterase, and cytochrome P450s. The action of these enzymes turns chemical compounds into less-toxic metabolites. Generally, enzymes from three families, cytochorome P450s, GSTs, and esterases, are involved in resistance towards insecticides. The increased rate of metabolism can result from a change in enzyme form or an increased rate of production of detoxification enzymes, which on the other hand is produced in much less quantities in susceptible insects (Hemingway et al., 1999; Siegfried and Scharf, 2001). Pyrethroids-resistant H. armigera from Australia has shown enhanced esterase activity. In the Indian strain of H. armigera, GSTs are involved in pyrethroids resistance (Gunning et al., 1996).

Biopesticides with a mode of action other than that of the conventional insecticides may reduce the risk of insecticide resistance and pest resurgence problems, while being com- 
paratively safe and ecologically acceptable. In early studies of safety evaluation against nontarget organisms, our candidate insecticide, cantharidin EC pesticide, in China had been found to have low toxicity against quail, ladybird beetles, and soil microorganisms (Cui et al., 2009). The insecticidal and antifeedant activities of cantharidin are well-established facts, as elucidated by Zhang et al. (2003) on the armyworm and diamond moth.

It is clear from the above review that metabolic enzymes play important roles in the detoxification of conventional insecticides and the development of resistance; however, these studies are lacking in information about the enzymes interactions with cantharidin. We report here the toxicity of cantharidin to H. armigera and the enzymatic responses of alkaline phosphatase and glutathione $S$-transferase. The major objectives of our study were to understand the effects of cantharidin, as a model toxin against the American bollworm, using toxicological and biochemical methods.

\section{MATERIAL AND METHODS}

\section{Reagents and chemicals}

p-Nitroanisol (BODI), Fast blue B salt (Urchem) 1-naphthol (Kermel), L-glutathione reduced (Wolsen), 1-naphthyl acetate (SCR), sodium barbital (ZIBO), 1-chloro-2,4-dinitrobenzene (CDNB; ABCR Chemicals), $p$-nitrophenol phosphate ( $p$-NPP; Amresco), and NADPH (Wolsen) were procured from the respective suppliers in parentheses. Other chemicals used in the experiments were of commercial grade.

\section{Laboratory extraction of cantharidin}

The cantharidin used in this study was extracted and purified (Carrel et al., 1985) in the laboratory using a standard protocol.

\section{Insects}

The $H$. armigera larvae used in this experiment were procured from Henan Jiyuan Baiyun Industry Co., Ltd. China and reared on an artificial diet (Ahmed and McCaffery, 1991).

\section{Bioassay}

The diet incorporation bioassay was used to determine the toxicity of cantharidin. Batches of healthy, homogeneous, third-instar $H$. armigera larvae were selected for bioassay. Cantharidin was added to the semi-solid artificial diet at the concentrations of $0.05,0.06,0.07$, 0.1 and $0.125 \mathrm{mg} / \mathrm{g}$, respectively, using acetone, and mixed well. The acetone was allowed to evaporate for $60 \mathrm{~min}$ before allowing the insects to feed. One larva of third instar was introduced to each cell of a 24-cell plastic bioassay tray. Twentyfour larvae of third instar were used per concentration per replication. The experiment was replicated three times. Mortality data were recorded for up to 5 days. The effect of $0.1 \mathrm{mg} / \mathrm{g}$ cantharidin on insect body weight was also calculated on the third-instar larvae. Data were recorded at 12, 24, 36, 48, and $56 \mathrm{~h}$ after treatment. 


\section{Induction treatment for enzyme assay}

The laboratory-prepared artificial diet mentioned above was mixed with $0.01 \mathrm{mg} / \mathrm{g}$ cantharidin, dissolved in acetone. The acetone was allowed to evaporate for $1 \mathrm{~h}$ before introduction of larvae to the diet. Acetone without cantharidin was mixed into the diet as the untreated control. Larvae of early third-instar, kept hungry for $8 \mathrm{~h}$, were introduced to the treated artificial diet. Samples were collected from the treatment and control groups at 12, 24, 36, and $48 \mathrm{~h}$ for determination of enzyme activity. Collected samples were flash-frozen and stored at $-80^{\circ} \mathrm{C}$ just after collection. Five larvae were used per replication both in the treatment and control groups. Three biological replicates were used in this experiment.

\section{Protein determination}

Protein contents within homogenates were determined according to the method of Bradford (1976), using bovine serum albumin as the standard.

\section{Specific activity of alkaline phosphatase and GST}

The method of Bessey (1964) was used for the determination of ALP specific activity. The rate of formation of the yellow color of $p$-nitrophenol, produced by the hydrolysis of $p$-NPP in alkaline solution, was measured spectrophotometrically at $405 \mathrm{~nm}$. Three biological replicates were used for both the treatment group and untreated control. Tissue homogenates were prepared by homogenizing larvae with a glass homogenizer in ALP buffer containing $0.824 \mathrm{~g}$ sodium barbital and $0.35 \mathrm{~mL} 0.2 \mathrm{M} \mathrm{HCl}$ mixed in $100 \mathrm{~mL}$ water. The tissue homogenates of the larvae were subjected to centrifugation at $10,000 \mathrm{rpm}$ at $4^{\circ} \mathrm{C}$ for $15 \mathrm{~min}$. The supernatants obtained were used as enzyme test solutions. The reaction was initiated with the addition of $2 \mathrm{~mL}$ ALP buffer and $0.5 \mathrm{~mL} 0.0075 \mathrm{M} p$-NPP to the enzyme test solution and placed for incubation at $37^{\circ} \mathrm{C}$ for $30 \mathrm{~min}$. Finally, $2 \mathrm{~mL} 0.5 \mathrm{M} \mathrm{NaOH}$ was used to terminate the reaction, and the ALP activity was determined spectrophotometrically at $405 \mathrm{~nm}$ after $5 \mathrm{~min}$.

The method of Booth et al. (1973) was followed for determining the specific activity of GST. Larvae were homogenized in $0.1 \mathrm{M}$ Tris-HCl buffer, $\mathrm{pH} 8.9$, on ice using a glass homogenizer. The homogenates were subjected to centrifugation at $10,000 \mathrm{rpm}$ for $15 \mathrm{~min}$ at $4^{\circ} \mathrm{C}$. The supernatants obtained were used as enzyme test solutions. Enzyme solution of 0.1 $\mathrm{mL}$ was mixed with $1.4 \mathrm{~mL} 0.1 \mathrm{M}$ Tris- $\mathrm{HCl}$ buffer, $\mathrm{pH} 8.9$ (containing $10 \mathrm{mM}$ glutathione) and incubated at $25^{\circ} \mathrm{C}$ for $10 \mathrm{~min}$. Then $60 \mu \mathrm{L} 30 \mathrm{mM}$ CDNB was added. The enzyme activity was measured spectrophotometrically at $340 \mathrm{~nm}$. The extinction coefficient of CDNB $\left(9.6 \mathrm{mM}^{-1}\right.$. $\mathrm{cm}^{-1}$ ) was used for calculation of the specific activity.

\section{RNA extraction and reverse transcription reaction}

Total RNA was extracted from the frozen insects at $-80^{\circ} \mathrm{C}$. Three biological replicates were used for both the treatment group and untreated control. Insects were homogenized using liquid nitrogen before the addition of RNAiso Plus (TaKaRa). RNA was extracted following the manufacturer instructions. The quality of RNA samples was examined by running them 
on agarose gels. DNase-I (Fermentas) was used to remove DNA contamination. cDNA was synthesized by reverse transcription using RevertAid ${ }^{\mathrm{TM}}$ Reverse Transcriptase (Fermentas) in a $20 \mu \mathrm{L}$ reaction containing $5 \mu \mathrm{L}$ total RNA (having $1 \mu \mathrm{g}$ RNA), $1 \mu \mathrm{L}$ oligo (dT) $)_{18}$ primer, $4 \mu \mathrm{L} 5 \mathrm{X}$ reaction buffer, $2 \mu \mathrm{L} 10 \mathrm{mM}$ dNTP mix, and $1 \mu \mathrm{L} 200 \mathrm{U} / \mu \mathrm{L}$ RevertAid ${ }^{\mathrm{TM}} \mathrm{M}-\mathrm{MuLV}$ Reverse Transcriptase. The reaction mixture was incubated for $60 \mathrm{~min}$ at $42^{\circ} \mathrm{C}$. The reaction was terminated by heating at $70^{\circ} \mathrm{C}$ for $10 \mathrm{~min}$. The product of the reverse transcription reaction was stored at $-80^{\circ} \mathrm{C}$.

\section{Gene cloning and sequencing}

The H. armigera alkaline phosphatase gene (GenBank accession No. EU729322) was amplified from cDNA by the polymerase chain reaction (PCR) using the upstream primer 5'-ATGGTGACACTGTTCCCGTACGT-3' and the downstream primer 5'-TTATCGCAGTA AAATGGAAGTGA-3', respectively. A Hind-III restriction site was incorporated into the sense primer, whereas a Bam-HI restriction site was incorporated into the antisense primer for the double-digestion reaction. The PCR amplification reaction was performed as follows: a first denaturation step for $3 \mathrm{~min}$ at $94^{\circ} \mathrm{C}$, followed by 30 cycles of $94^{\circ} \mathrm{C}$ for $30 \mathrm{~s}, 60^{\circ} \mathrm{C}$ for $45 \mathrm{~s}$, and $72^{\circ} \mathrm{C}$ for $2 \mathrm{~min}$ and a final extension of $7 \mathrm{~min}$ at $72^{\circ} \mathrm{C}$. The glutathione $S$-transferase gene (GenBank accession No. EF033109) was PCR-amplified from cDNA using the upstream primer 5'-ATGTCCTTAGACTTGTATTACG-3' and the down-stream primer 5'-TTACAATT CAGTTTTAGCTTTT-3', respectively. A Pst-I restriction site was incorporated into the sense primer, whereas an Eco-RI restriction site was incorporated into the antisense primer for the double-digestion reaction. The PCR amplification reaction was performed as follows: a first denaturation step for $3 \mathrm{~min}$ at $95^{\circ} \mathrm{C}$, followed by 34 cycles of $95^{\circ} \mathrm{C}$ for $30 \mathrm{~s}, 55^{\circ} \mathrm{C}$ for $30 \mathrm{~s}$, and $72^{\circ} \mathrm{C}$ for $1 \mathrm{~min}$ and a final extension of $5 \mathrm{~min}$ at $72^{\circ} \mathrm{C}$. The PCR products were run on a $1 \%$ agarose $(\mathrm{w} / \mathrm{v})$ gel and visualized by ethidium bromide staining using a BioRad imaging system. The amplified products of the target genes were gel-purified using a gel extraction kit (Biomiga). The gel-purified PCR products were then ligated to the pMD-19T vector (Ta$\mathrm{KaRa}$ ) and transformed into Escherichia coli DH5 $\alpha$. The transformants were selected on LB (Lauria-Bertani) agar plates containing $100 \mu \mathrm{g} / \mathrm{mL}$ ampicillin after an overnight incubation at $37^{\circ} \mathrm{C}$. At first, the presence of the target genes was identified by double-restriction digestion of plasmids extracted from positive clones. Resultant clones were then sequenced by Shanghai Sunny Biotech Co., Ltd.

\section{Sequence analysis and phylogenetic analysis}

The obtained sequences were analyzed using the DNAman software package (Lynnon, Quebec, Canada). The amino acid sequence was deduced by the ExPASy tool (http://web. expasy.org/translate/) and used for a BLAST search against registered amino acid sequences to determine its conformity with target sequences.

\section{Semi-quantitative RT-PCR analysis for gene expression}

The expression level of the HaALP gene transcript was examined by semi-quantitative RT-PCR analysis of the cDNAs synthesized from RNAs isolated from insects treated with 
cantharidin at different intervals. Two gene-specific primers, sense (5'-GGACCTGCCTGAA TACAT-3') and antisense (5'-TTGCCACCTCTGTTAGTT-3'), were designed to amplify the 110 bp cDNA fragment of HaALP using Beacon Designer 7 (Premier Biosoft). To normalize the gene expression, the $H$. armigera $\beta$-actin gene (GenBank accession No. EU527017) was used as an endogenous control. The PCR condition used were as follows: $95^{\circ} \mathrm{C}$ for 3 min, followed by 30 cycles of $95^{\circ} \mathrm{C}$ for $30 \mathrm{~s}, 60^{\circ} \mathrm{C}$ for $50 \mathrm{~s}$, and $72^{\circ} \mathrm{C}$ for $1 \mathrm{~min}$, and a final extension at $72^{\circ} \mathrm{C}$ for $5 \mathrm{~min}$. The expression level of the HaGST gene transcript was likewise examined by semi-quantitative RT-PCR analysis of the cDNAs synthesized from RNAs isolated from insects treated with cantharidin at different intervals. Two gene-specific primers, sense (5'-ACGCTTTACCCAAGATTTG-3') and antisense (5'-GGAATGTGTTGAGGAAG TG-3'), were designed to amplify the 110 bp cDNA fragment of HaGST using Beacon Designer 7. The $H$. armigera $\beta$-actin gene was again used as the endogenous control, amplified using a sense (5'-GTATTGCTGACCGTATGC-3') and antisense (5'-ATCTGTTGGAAGG TGGAG-3') primer pair. The PCR condition used were $95^{\circ} \mathrm{C}$ for $3 \mathrm{~min}$, followed by 30 cycles of $95^{\circ} \mathrm{C}$ for $30 \mathrm{~s}, 55^{\circ} \mathrm{C}$ for $35 \mathrm{~s}$, and $72^{\circ} \mathrm{C}$ for $1 \mathrm{~min}$, and a final extension at $72^{\circ} \mathrm{C}$ for $5 \mathrm{~min}$. Electrophoresis and visualization of the amplified products were performed as mentioned above.

\section{Statistical analysis}

Probit analysis was used to determine the different LC values for cantharidin after acquiring data from bioassay experiment (Finney, 1971). SPSS 17.0 software was used for analysis of photometric data (SPSS Inc., Chicago, IL). Significance of the effect of cantharidin on enzymes specific activity was determined by independent $t$-test. Means were considered to be significantly different at $\mathrm{P} \leq 0.05$.

\section{RESULTS}

\section{Bioassay}

The bioassay results showed that the concentrations of cantharidin used affected $H$. armigera and caused low to high mortality depending on the concentration and time. The mortality of cantharidin at higher dose after different intervals was significantly high. Different LC values were calculated, using the mortality data, to determine the lethal and sublethal doses. The $\mathrm{LC}_{50}$ of cantharidin was found to be $0.068 \mathrm{mg} / \mathrm{g}$. The sublethal dose $\left(\mathrm{LC}_{10}\right.$ of $\left.0.01 \mathrm{mg} / \mathrm{g}\right)$ was used for the enzyme assay.

\section{Cloning and sequencing analysis}

Gene-specific primers were used to clone HaALP and HaGST. Bands of $1608 \mathrm{bp}$ (Figure 1A) and $663 \mathrm{bp}$ (Figure 1B) for HaALP and HaGST, respectively, were visualized on the agarose gel. The sequencing results from Shanghai Sunny Biotech Co., Ltd. were verified by a nucleotide BLAST search of the NCBI database (http://www.ncbi.nlm.nih. gov/), and the deduced amino acids sequences were verified by a BLAST search of the Protein Data Base. 
A

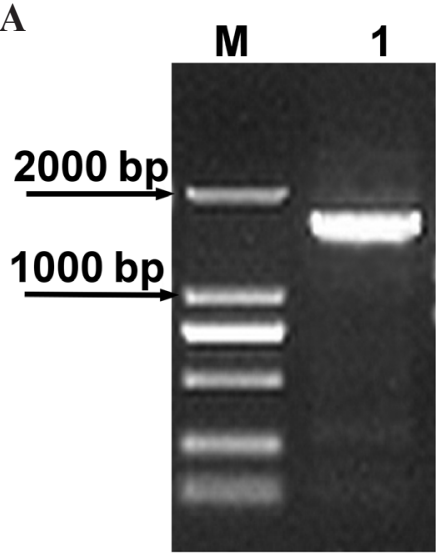

B B $\quad M \quad 1$

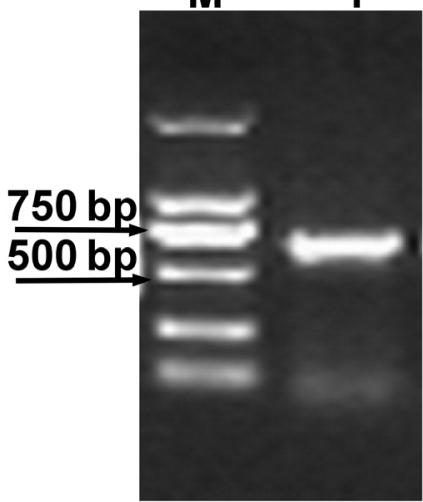

Figure 1. Amplification of HaALP and HaGST genes by PCR reaction using gene specific primers. Amplification of HaALP gene of $1608 \mathrm{bp}(\mathbf{A})$ and amplification of HaGST gene of $663 \mathrm{bp}(\mathbf{B})$.

\section{Specific activity of ALP and GST}

A non significant increase in ALP activity was seen at $12 \mathrm{~h}$ after treatment, but it started to decline thereafter. Highly significant inhibition of ALP was observed at the end of $48 \mathrm{~h}(\mathrm{P} \leq 0.01)$ (Figure 2$)$. The GST activity was slightly higher in the treatment group as compared with the control at $12 \mathrm{~h}$. At the end of the $24 \mathrm{~h}$ interval, the enzyme activity in the treatment group was significantly lower $(\mathrm{P} \leq 0.05)$ as compared with the control. The highly significant activity inhibition trend was also seen at 36 and $48 \mathrm{~h}$, respectively $(\mathrm{P} \leq$ 0.01 ) (Figure 3).

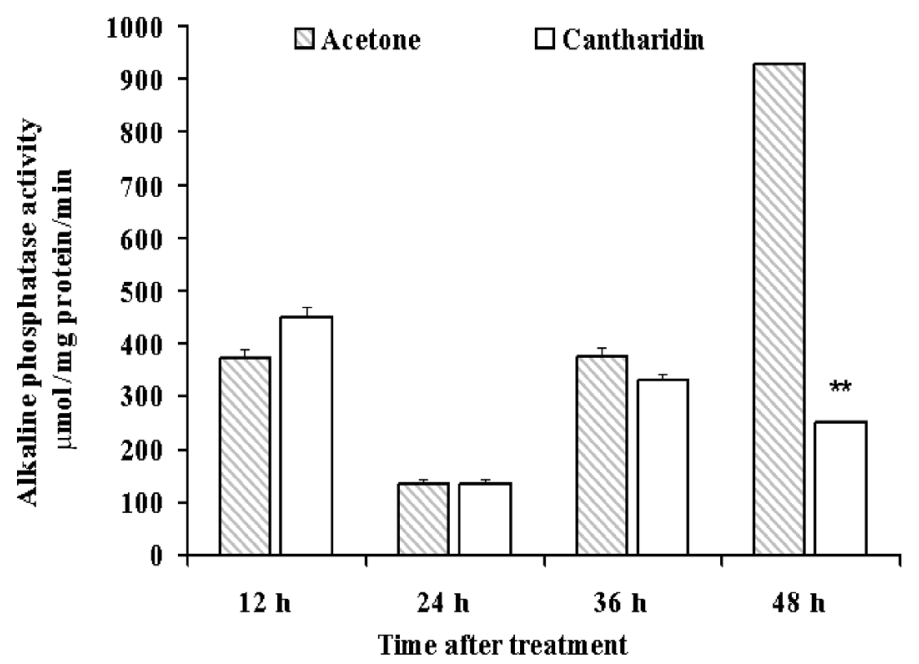

Figure 2. Specific activity of alkaline phosphatases at different intervals after treatment. Asterisks show significant difference between control and treatment by independent $t$-test at $\mathrm{P} \leq 0.05$. 


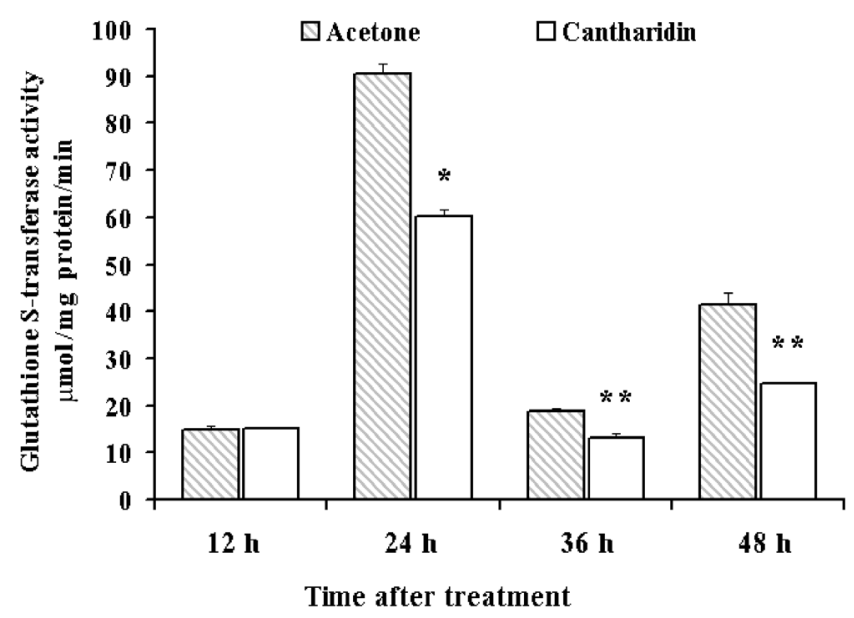

Figure 3. Specific activity of glutathione $S$-transferases at different intervals after treatment. Asterisks show significant difference between control and treatment by independent $t$-test at $\mathrm{P} \leq 0.05$.

\section{Expression levels of ALP and GST}

In order to understand the effect of cantharidin on the expressions of ALP and GST, their expression levels were examined at different time intervals after treatment, by semiquantitative RT-PCR. The results revealed that the ALP transcript level remained slightly high at $12 \mathrm{~h}$ after treatment, compared with the untreated control. However, this trend changed after $12 \mathrm{~h}$ and the level started declining at 24,36, and $48 \mathrm{~h}$, respectively (Figure 4). In the case of GST, no obvious change was seen in transcript levels at $12 \mathrm{~h}$ after treatment; however, the transcription level started to decline at a steady pace at 24, 36, and $48 \mathrm{~h}$ (Figure 5). The down-regulation in ALP expression at $48 \mathrm{~h}$ was quite obvious, with the transcript level showing a 7.69-fold decline (Figure 6A), whereas the transcript level of GST at $48 \mathrm{~h}$ showed a 2.32-fold decline as compared with the control (Figure 6B).

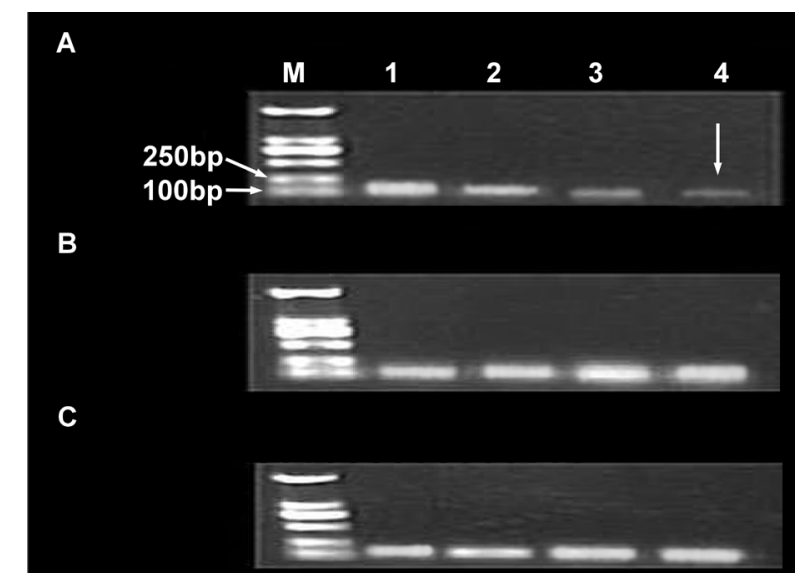

Figure 4. Semi-quantitative RT-PCR analysis of HaALP transcript levels. A. Treatment; B. untreated control; and C. $\beta$-actin as an internal control. Lane $M=$ DNA marker; lanes $1-4=$ time interval after treatment of $12,24,36$, and $48 \mathrm{~h}$. 


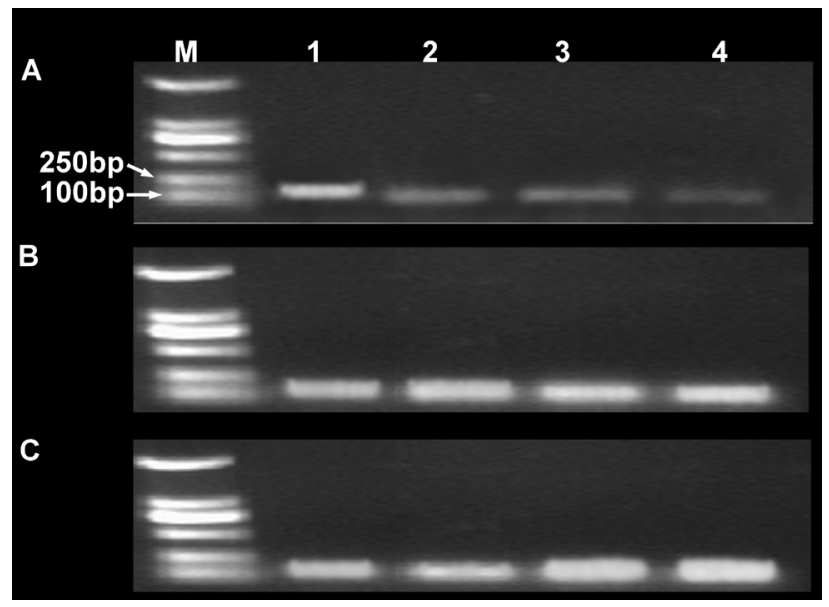

Figure 5. Semi-quantitative RT-PCR analysis of HaGST transcript levels. A. Treatment; B. untreated control; and C. $\beta$-actin as an internal control. Lane $M=$ DNA marker; lanes $1-4=$ time interval after treatment of $12,24,36$, and $48 \mathrm{~h}$.

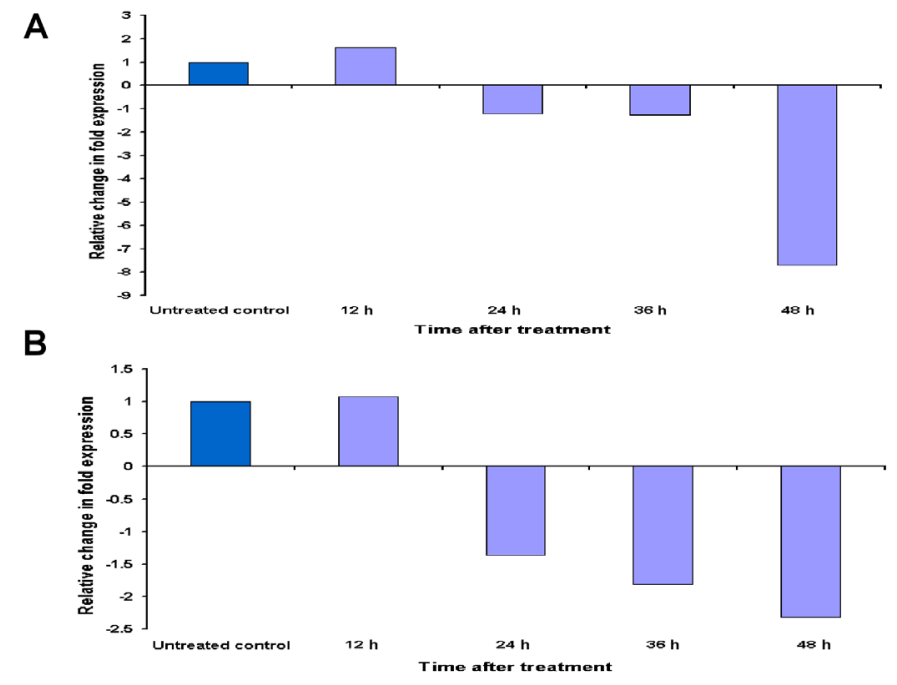

Figure 6. Fold change in transcript levels. A. Transcription levels of HaALP. B. Transcription levels of HaGST. Imagej was used to calculate the band intensity and to calculate fold change in transcription levels of treatment compared with the untreated control.

Cantharidin treatment of larvae resulted in retarded growth. The body weights of larvae feeding on artificial diet containing $0.1 \mathrm{mg} / \mathrm{g}$ cantharidin were significantly lower than those of larvae feeding on untreated artificial diet (Figure 7). No significant weight loss was recorded at $12 \mathrm{~h}$ after treatment. However, significant body weight loss was recorded at 24 to $56 \mathrm{~h}$ after treatment, compared with the untreated control. Insects fed on cantharidin-containing artificial diet presented a dark brownish necrotic look after death. However, no rupture of tissue or fluid was seen on the treated larvae. The size of the larvae also remained small as compared with controls (Figure 8). 


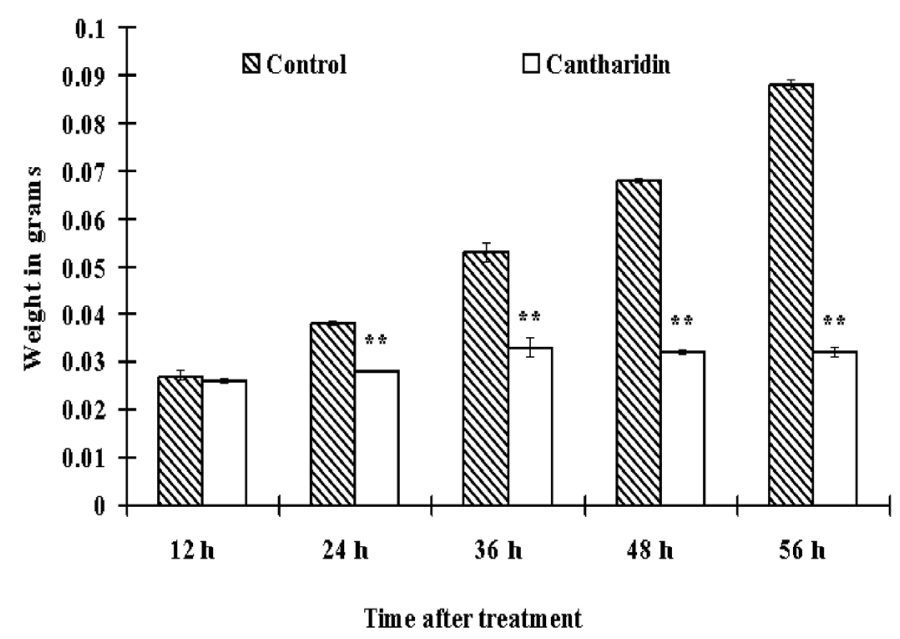

Figure 7. Effect of cantharidin treatment on the body weight of Helicoverpa armigera larvae at different intervals after treatment. Asterisks show significant differences between control and treatment.

A

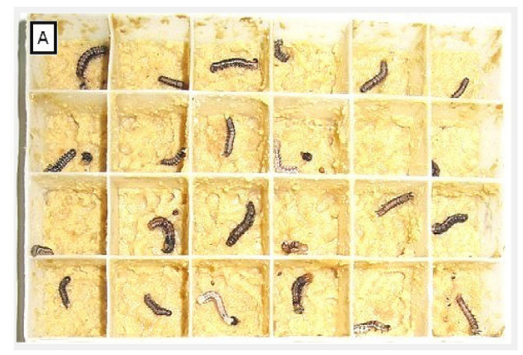

C
B

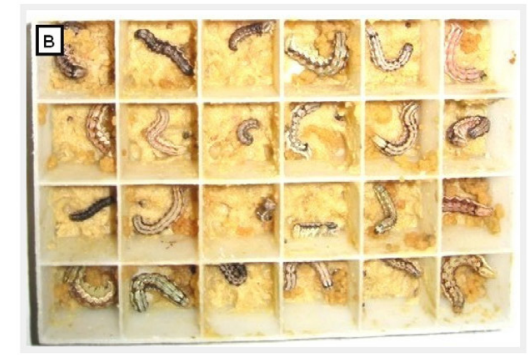

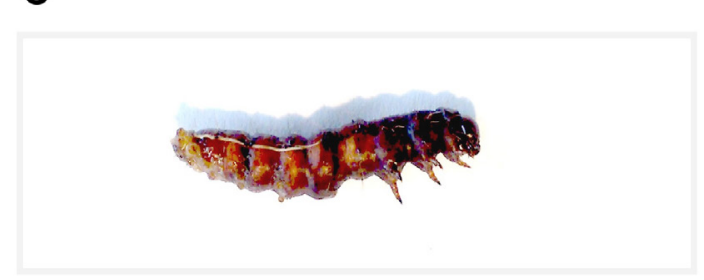

Figure 8. Morphological structure of Helicoverpa armigera. A. Larvae treated with cantharidin; B. untreated larvae; and $\mathbf{C}$. structure of the larvae died after treatment with cantharidin.

\section{DISCUSSION}

Cantharidin was incorporated into artificial diet, and third-instar H. armigera larvae were allowed to feed on it for up to 5 days. The result was that cantharidin caused mortality in a concentration-dependent manner. Exposure to cantharidin also reduced the activity of the metabolic enzymes alkaline phosphatase and glutathione $S$-transferase. 
Earlier studies have shown that the toxicity of cantharidin is a result of its binding to phosphoprotein 2A (PP2A). Other than PP2A, the detailed physiological and biochemical effects of cantharidin and its mechanism of action remain largely unknown (Decker, 1968; Bagatell et al., 1969; Graziano and Casida, 1987; Graziano et al., 1987; Kawamura et al., 1990). In our experiment, cantharidin treatment at a sublethal dose significantly reduced the level of ALP in vivo. The reduced level of ALP suggests that energy metabolism may have been directly affected by cantharidin, by reducing the level of phosphorus liberation that in turn decreases metabolism as well as the transport of metabolites. Similar effects of azadirachtin and nucleopolyhedrovirus were observed on ALP and other digestive enzymes (Huang et al., 2004; Senthil-Nathan et al., 2005).

In our study cantharidin also reduced the weights of larvae. This could have been due to the decreased level of enzymes activity and the resultant general disturbance in metabolism in the cantharidin-treated insects.

In previous studies, high levels of esterases and phosphatases, in resistant insects as compared with susceptible insects, were shown to be involved in the resistance mechanism. They were suggested as being involved in increased metabolism and the development of resistance towards insecticides (Srinivas et al., 2004). The suppression of alkaline phosphatase activity by cantharidin could be one of the mechanisms of its toxicity in our experiment. Similarly, the involvement of glutathione $S$-transferase has been reported by many authors, and its increased level has been attributed to the mechanism of resistance in several pests (Balabaskaran and Chuen, 1989; Yu and Ngugen 1992; Mohan and Gujar, 2003). The inhibitory effect of cantharidin on glutathione $S$-transferase suggests the inability of the enzyme to metabolize cantharidin.

In conclusion, cantharidin was found to be toxic against $H$. armigera in the concentrations used. The reduced activities of alkaline phosphatase and glutathione $S$-transferase confirmed by molecular and biochemical means, showed the inability of these enzymes to metabolize cantharidin, which may be the possible target mechanism of cantharidin.

\section{ACKNOWLEDGMENTS}

Research supported by the Special Fund for the Public Interest (Agriculture) (\#200903052) by The Ministry of Science and Technology of China and The Ministry of Agriculture, China, and the "13115" Sci-Tech Innovation Project of Shaanxi Province (\#2007ZDKG-14).

\section{REFERENCES}

Ahmed M and McCaffery AR (1991). Elucidation of detoxification mechanisms involved in resistance to insecticides against third instar larvae of a field selected strain of Helicoverpa armigera with the use of synergists. Pestic. Biochem. Physiol. 41: 41-52.

Ahmed M, Arif MI and Ahmed Z (1995). Monitoring insecticide resistance of Helicoverpa armigera (Lepidopetra: Noctuidae) in Pakistan. J. Econ. Entomol. 88: 771-776.

Armes NJ, Jadhav DR, Bond GS and King ABS (1992). Insecticide resistance in Helicoverpa armigera in South India. Pestic. Sci. 34: 355-364.

Bagatell FK, Dugan K and Wilgram GF (1969). Structural and biochemical changes in tissues isolated from the cantharidinpoisoned rat with special emphasis upon hepatic subcellular particles. Toxicol. Appl. Pharmacol. 15: 249-261.

Balabaskaran MM and Chuen SS (1989). Glutathione-S-transferase from the diamondback moth. Insect Biochem. 19: 
435-443.

Bessey OA (1964). A method for the rapid determination of phosphatase with five cubic millimeter of serum. J. Biol. Chem. 164: 321-329.

Bhatnagar VS, Lateef SS, Sithanantham S, Pawar CS et al. (1982). Research on Heliothis at ICRISAT. In: Proceedings of the International Workshop on Heliothis Management, Patancheru, 385-396.

Booth GM, Connor J, Metcalf RA and Larsen JR (1973). A comparative study of the effects of selective inhibitors on esterase isozymes from the mosquito Anopheles punctipennis. Comp. Biochem. Physiol. B 44: 1185-1195.

Bradford MM (1976). A rapid and sensitive method for the quantitation of microgram quantities of protein utilizing the principle of protein-dye binding. Anal. Biochem. 72: 248-254.

Carrel JE, Doom JP and McCormick JP (1985). Quantitative determination of cantharidin in biological materials using capillary gas chromatography with flame ionization detection. J. Chromatogr. 342: 411-415.

Cui FL, Li X, Ma ZQ and Zhang YL (2009). Safety evaluation of animal-origin pesticide cantharidin against some nontarget organisms. J. Enivron. Entomol. 31: 143-149.

Decker RH (1968). The identification of a phosphoprotein in acantholytic epidermis. J. Invest. Dermatol. 51: 141-146.

EPPO (1996). EPPO Reporting Service. EPRO, Paris.

Finney DJ (1971). Probit Analysis. 3rd edn. Cambridge University Press, London.

Graziano MJ and Casida JE (1987). Comparison of the acute toxicity of endothal and cantharidic acid on mouse liver in vivo. Toxicol. Lett. 37: 143-148.

Graziano MJ, Waterhouse AL and Casida JE (1987). Cantharidin poisoning associated with specific binding site in liver. Biochem. Biophys. Res. Commun. 149: 79-85.

Gunning RV, Easton CS, Balfe ME and Ferris IG (1991). Pyrethroid resistance mechanisms in Australian Helicoverpa armigera. Pestic. Sci. 33: 473-490.

Gunning RV, Moores GD and Devonshire AL (1996). Esterases and Esfenvalerate resistance in Australian Helicoverpa armigera (Hubner) (Lepidoptera: Noctuidae). Pestic. Biochem. Physiol. 54: 12-23.

Hemingway J, Hawkes N, Prapanthadara L and Indrananda J (1999). The Role of Gene Splicing, Gene Amplification and Regulation in Mosquito Insecticide Resistence. In: Insecticide Resistance: from Mechanisms to Management (Denholm I, Pickett JA and Devonshire AL, eds.). CABI Publishing, London, 19-23.

Huang Z, Shi P, Dai J and Du J (2004). Protein metabolism in Spodoptera litura (F.) is infuenced by the botanical insecticide azadirachtin. Pestic. Biochem. Physiol. 80: 85-93.

ICRISAT (2003). Annual Report. ICRISAT, Patancheru.

Kawamura N, Li Y-M, Engel JL, Dauben WG, et al. (1990). Endothall thioanhydride: structural aspects of unusually high mouse toxicity and specific binding site in liver. Chem. Res. Toxicol. 3: 318-324.

Kennaugh L, Pearce D, Daly JC and Hobbs AA (1993). Piperonyl butoxide synergizable resistance to permethrin in Helicoverpa armigera which is not due to increased detoxification by cytochrome P450. Pestic. Biochem. Physiol. 45: 234-241.

Mohan M and Gujar GT (2003). Local variation in susceptibility of the diamondback moth, Plutella xylostella (L.) to insecticides and role of detoxification enzymes. Crop Prot. 22: 495-504.

Ramasubramanian T and Regupathy A (2004). Evaluation of indoxacarb against Pyrethroid resistant population of Helicoverpa armigera Hub. J. Entomol. 1: 21-23.

Senthil-Nathan S, Kalaivani K, Murugan K and Chung PG (2005). The toxicity and physiological effect of neem limonoids on Cnaphalocrocis medinalis (Guenée) the rice leaf folder. Pestic. Biochem. Physiol. 81: 113-122.

Siegfried BD and Scharf ME (2001). Mechanisms of Organophosphate Resistance in Insects. In: Biochemical Sites of Insecticide Action and Resistance (Ishaaya I, ed.). Springer-Verlag, Berlin, 269-321.

Srinivas R, Udikeri SS, Jayalakshmi SK and Sreeramulu K (2004). Identification of factors responsible for insecticide resistance in Helicoverpa armigera. Comp. Biochem. Physiol. C Toxicol. Pharmacol. 137: 261-269.

West AJ and McCaffery AR (1992). Evidence of Nerve Insencitivity to Cypermethrin from Indian Strains of H. armigera. In: Proceedings of the Brighton Crop Protection Conference: Pests Diseases, 23-26 Nov. 1992, Brighton, United Kingdom. The British Crop Protection Council, Farnham, 233-238.

Yu SJ and Nguyen SN (1992). Detection and biochemical characterization of insecticide resistance in the diamondback moth. Pestic. Biochem. Physiol. 44: 74-81.

Zhang YL, Zhou Y and Zhang ZY (2003). Effect of cantharidin on the midgut of orient armyworm (Methimna seperata) and diamond moth Plutella xylostella. Acta Entomol. Sin. 46: 272-276. 